\title{
FOKUS: OLJEFONDET OG UTENRIKSPOLITIKKEN
}

\section{Norge, Oljefondet og sårbare stater}

\author{
MORTEN BØÅS $\star$
}

Dr. Polit, Forskningsprofessor, Norsk utenrikspolitisk institutt

Den liberale optimismen som hersket ved århundreskiftet er nå erstattet av en almenn oppfatning om at vi lever i en hardere, mer realistisk orientert verden. Dagens situasjon preges av en rekke større og mindre kriser. I Sahel og deler av Sentral-Asia blir statene stadig mer sårbare. Det innebærer at slike stater er i ferd med både å miste monopol på bruk av tvangsmakt innenfor egne grenser så vel som kontroll over sine ytre grenser. I en slik situasjon er ikke lengre staten det dominerende senteret for avveining av ulike politiske stridsspørsmål, men kun en av flere aktører som konkurrerer om å innta denne rollen. Det betyr at $i$ en sårbar stat som dette kan en ikke-statlig væpnet bevegelse være like relevant for menneskers levekår som det formelle byråkratiske apparatet til staten.

I Midtøsten har Den islamske staten endret det geopolitiske kartet som har ligget fast siden britene og franskmennene trakk opp grensene mellom de nye statene i regionen etter Den første verdenskrig (Sykes-Picot-avtalen fra 1919). Forholdet mellom Russland og Vesten er betent etter førstnevntes annektering av Krimhalvøya. Europa sliter med stagnasjon og finans- og gjeldskrise, spesielt i sør. Flyktninger flommer over Europas grenser i et høyere antall enn hva vi har sett siden Den andre verdenskrig. Samtidig utgjør disse flyktningene kun en liten brøkdel av de rundt 60 millionene som enten lever som flyktninger eller internt fordrevne i fattige og sårbare stater andre steder.

Verden er i endring. Den er mer multipolar, med store geopolitiske forskyvninger. Makt flyttes og flyter rundt i en verden som har blitt betydelig mer kompleks politisk, sosialt, økonomisk og militært. Midt oppe i alt dette sitter Norge med sitt oljefond. Et av verdens største investeringsfond med 7457 milliarder på bok. Dette fondet har investeringer i 9000 selskaper i 75 land. Med dette fondet eier Norge 1,3 prosent av verdens børsnoterte selskaper, 2,4 prosent av alle europeiske selskaper, og i tillegg en betydelig mengde verdipapirer og bygningsmasse.

Dette er en høyst uvanlig situasjon. Det er egentlig ingen vi kan sammenlikne oss med. Det har aldri før eksistert et lite land, i utkanten av verdenssystemet som har kontrollert så mye av verdens samlede verdier. Norges posisjon er derfor høyst spesiell,

^Korrespondanse: Morten Bøås, Forskningsprofessor, Norsk utenrikspolitisk institutt. Email: mbo@nupi.no 
men dette snakkes det nesten ikke om. Det burde vi, for dette har implikasjoner for hvordan vi bør navigere i det krevende geopolitiske terrenget vi nå står overfor. Vi må bare innse det: Vi er ikke en vanlig europeisk småstat, men en oljestat som har spredt vår enorme formue på ulike investeringer rundt omkring i hele verden. For Norge som utenrikspolitisk aktør betyr dette at Norge har utenrikspolitiske interesser langt utenfor våre nærområder. Vi driver ikke kun med bistand i fattige deler av verden, vi er også en betydelig finansiell aktør som påvirker politikk og politiske veivalg. Vi er altså en global aktør, men hva betyr dette for Norge? Hvordan skal vi handtere både våre kortsiktige og langsiktige sikkerhetsinteresser i lys av dette? Og kan vi etablere en helhetlig utenrikspolitikk som tar høyde for hvem vi egentlig er?

Dette fokusbidraget vil ikke belyse alle disse problemstillingene fullt ut. Snarere er ambisjonen å se litt nærmere på forholdet mellom norsk utenrikspolitikk og oljefondets investeringer i Afrika. Dette er den verdensregionen undertegnede kjenner best. Jeg kommer til å trekke opp noen utfordringer, antyde noen muligheter og reise noen spørsmål knyttet til hvordan Norge bør forholde seg til kontinentets sårbare stater, noe jeg mener fortjener en bredere debatt. Poenget er ikke å argumentere for en mer altruistisk bruk av Oljefondets ressurser i sårbare stater, men å åpne en debatt om hvordan den globale spredningen av vår formue best kan beskyttes på en slik måte at vi øker både vår egen og andres sikkerhet. Gjennom fondet har vi blitt en global aktør, og vår fremtidige økonomiske sikkerhet er dermed knyttet til global sikkerhet. En sikkerhet som i dag utfordres ikke kun av tradisjonelle sikkerhetstrusler, men vel så mye av de komplekse geopolitiske forskyvningene som oppstår når stater reelt sett slutter å fungere som suverene stater med et monopol på bruk av vold og kontroll over egne grenser.

\section{Norge og Afrika - fra bistand til investeringer i kollektiv sikkerhet?}

Tradisjonelt har forholdet mellom Norge og Afrika vært oppfattet som en relasjon hvor ambassader og bistand fulgte i fotsporene til norske misjonærer. Dette er på mange måter en korrekt fremstilling av Norges historie som en aktør på det afrikanske kontinentet. Mye på grunn av språk dro brorparten av de første norske misjonærene til verdensdelens engelskspråklige områder som Øst-Afrika. Det var også i Tanzania at Norge i 1962 først begynte som bistandsaktør i Afrika, ti år etter at norsk bistand ble etablert med fiskerihjelpen til Kerala i India (se Simensen 2003).

Dette er bistandshistorie og den vanlige oppfatningen er fortsatt at Afrikas rolle i norsk utenrikspolitikk er som en mottaker av norsk bistand. I den grad det er brudd i denne historien så handler det mest om norsk tilpasning til internasjonale trender, fra strukturtilpasning og godt styresett til en mer markedsliberalistisk tilnærming som legger sterkere vekt på investeringer enn det som tidligere var vanlig. Norge er i Afrika som giver, og ikke som en stat som bruker Afrika som et marked for å tjene penger eller sørge for egen sikkerhet. Men hvis dette er korrekt så representerer tallene for Oljefondets totale investeringer et skarpt brudd med Norges etablerte praksis når det gjelder forholdet til Afrika. 
Oljefondet har i løpet av sin eksistens investert 28, 685226925 milliarder norske kroner i aksjer i afrikanske selskaper eller internasjonale selskaper som opererer i Afrika, og plassert 13287661781 norske kroner i rentepapirer knyttet til det afrikanske kontinentet. Den tilsvarende summen i norske kroner i bistand til Afrika i 2014 var på 6335300000 kroner. De summene som oljefondet representerer er et helt nytt element i forholdet mellom Norge og Afrika. Riktig nok har Norge som vi skal se også en relativt lang historie som kommersiell aktør på dette kontinentet. Dette knytter noen linjer til dagens situasjon med Oljefondet. Likevel er det oppsiktsvekkende hvor fraværende denne kommersielle delen av Norges virksomhet i Afrika er fra den allmenne norske debatten om Afrika.

Den norske utviklingshjelpen til Afrika startet som sagt i Tanzania, spredte seg rask utover det østlige og sørlige Afrika, og omfattet i begynnelsen stort sett sektorer som jordbruk, infrastruktur og energi, og noe industri. Dette var stat til stat-bistand, men ofte var det også en næringslivskomponent tilstede. Denne komponenten var kanskje ikke så veldig omfattende, men likevel var den så avgjort tilstede. I startfasen $\mathrm{i}$ Øst-Afrika gikk for eksempel mye av den norske bistanden til veibygging, og i slike prosjekter ble også norske entrepenørselskaper trukket inn, for eksempel Veidekke. Da det i denne perioden ofte var nordmenn som satt med planleggingsansvar og myndighet også på afrikansk side, åpnet det seg muligheter for norske selskaper. Slik skapte bistandsbevilgningene et marked for norsk næringsliv i Øst-Afrika. Der det fra før av nesten ikke hadde vært kommersiell norsk virksomhet, ble det nå åpnet opp et nytt marked for norske kommersielle interesser (Simensen 2003). Norsk bistand skapte dermed muligheter for norsk eksport, men denne siden av Norges relasjon til Afrika har i liten grad vært gjenstand for mer allmenn debatt.

Tradisjonelt har den norske offisielle tilstedeværelsen i det fransktalende Afrika og dermed Vest-Afrika vært mye mindre. Med unntak av land som Mali har det vært få norske misjonsorganisasjoner og kristne hjelpeorganisasjoner tilstede, og med unntak av Nigeria og senere Ghana er det få norske utestasjoner (les ambassader) i denne delen av Afrika. Det er derfor nesten merkelig at norsk næringsvirksomhet har vært virksom her i relativt lang tid. Faktisk har norsk næringslivs interesse for den vestafrikanske kysten til tider vært større enn for de delene av Afrika hvor Norge formelt sett er representert. I så måte er dette et godt eksempel på hvordan norsk utenrikspolitisk virksomhet i Afrika representerer et brudd med vår diplomatiske historie hvor 'flagget fulgte skipene' (se Bjørgo 1995), dvs. våre strategiske økonomiske og politiske interesser. Men i og med at Afrika i norsk offentlighet ble definert som et område kun for norsk bistand ble dette lite vektlagt, og norske selskaper som opererte i Afrika fikk stort sett lite oppmerksomhet. Dette var i all hovedsak situasjonen frem til Erik Solheim tok over som bistandsminister og begynte å snakke om fattige lands behov ikke kun for bistand, men også for utenlandsinvesteringer. Dette har ført til sporadiske debatter om norsk næringslivsvirksomhet i land som Angola og Nigeria, men ingen større strategisk debatt om Norges økonomiske og politiske forhold til og posisjon i Afrika. Vi oppfatter oss og opptrer som om vi er en småstat uten verken strategiske interesser eller spesielle forpliktelser. 
Mye av det samme kan sies om Oljefondet i Afrika. Det bare er der og tjener penger i det stille. Mens de rundt 6 milliardene vi brukte på bistand i Afrika i 2014 ofte diskuteres heftig, ser det ut til at de over 41 milliardene som Norge ved Oljefondet har investert i Afrika ikke eksisterer i en offentlig sammenheng. Det er ikke bare merkelig, men rett og slett en illusjon at slike summer anses som politisk ugyldige. Slike summer og slike investeringer kan aldri sies å være politisk nøytrale. De påvirker ikke kun fordelingsspørsmål, men også interne maktforhold. At de påvirker maktforhold er ikke nødvendigvis noe galt i seg selv. Problemet er at det er en viktig arm av norsk utenriksvirksomhet, bredt definert, som vi omtrent aldri diskuterer. Dette er hva NUPIs direktør Ulf Sverdrup har kalt 'gorillaen i rommet': den store, tunge aktøren som er tilstede og tar opp mye plass, men som alle de andre later som ikke er der (se Sverdrup 2013). Spørsmålet er om ikke den situasjonen vi står overfor i dag fordrer at vi tenker gjennom dette på nytt. Vi er ingen småstat lengre. Økonomisk sett er vi gjennom Oljefondet en tung, global aktør som er nødt til å vurdere hvilken plass denne institusjonen skal ha innenfor norsk utenrikspolitikk. Våre investeringer er langsiktige, og de sikres best gjennom bidrag til en mer stabil og fredelig verden. Det burde være mulig å tenke mer systematisk på hvordan fondet kan bidra i så måte og slik også bidra til å sikre vår fremtidige formue både globalt og i de delene som er plassert på Det afrikanske kontinentet. Dette vil heller ikke innebære et større linjeskift i norsk utenrikspolitikk da vi allerede er engasjert i samarbeid om fred og sikkerhet med afrikanske partnere. Dette samarbeidet ble ytterligere styrket i 2015 da Norge undertegnet en ny samarbeidsavtale med Den afrikanske union (AU) knyttet til fred og sikkerhet, demokrati og styresett, og bærekraftig utvikling og jobbskaping (se Utenriksdepartementet 2015). Spesielt innenfor det siste tema ville en bredere diskusjon om Oljefondets rolle være høyst relevant.

\section{Investering i sårbare stater - utfordringer og handlingsrom?}

Alle stater er sårbare på en eller annen måte. Derfor er det ikke slik at alle stater som i dag defineres som sårbare er like utsatt for å få statens monopol på bruk av vold underminert. Samtidig er det slik at jo svakere en stat er, jo større sjanse er det for at væpnede, ikke-statlige grupper kan skaffe seg tilhold der. Dette ser man tydelig i de fleste konfliktområdene i dag. Spørsmålet er derfor om utenlandsinvesteringer kan bidra til å øke slike staters motstandskraft mot statssammenbrudd?

I Afrika, er Sahel den regionen hvor vi ser samspillet mellom sårbare stater og forverrede levekår tydeligst. I denne delen av Afrika er flere av statene svekket og deres autoritet utfordres av flere typer ikke-statlige aktører. Tradisjonelle levekår er sterkt forringet på grunn av klimaendringer. Det blir tørrere. Regnet kommer sjeldnere, og det kommer ikke i de vante, sykliske svingningene. Et mindre forutsigbart klima betyr at bøndene ikke kan planlegge året slik de pleide å gjøre, og når regnet kommer så får de ikke benyttet seg av det. Om de så hadde villet det, så har de fleste statene i Sahel ikke et tilstrekkelig ressursgrunnlag på nåværende tidspunkt til å sette inn effektive tiltak for å motvirke dette (Bøås 2015). 
Det betyr at hvis noen andre ikke kommer til med umiddelbar humanitær assistanse kombinert med langsiktige investeringer som kan skape nye næringsveier, så har folk som bor i dette området egentlig bare to valg. Enten å flytte, som dermed vil innebære at enda fler vil begi seg ut på vandring mot Europa, eller å finne noe annet å leve av der de bor. Hvis vi ikke er til stede og bidrar, vil det åpne seg handlingsrom for andre, alternative aktører. Disse aktørene kan være transnasjonalt organiserte kriminelle, lokale smuglere, men også ulike ikke-statlige væpnede bevegelser, det være seg jihadister, eller andre mer sekulære grupperinger. Her vil det ofte være en glidende overgang både mellom grupper og mellom folk som beveger seg rundt i regionen. Nesten alle de væpnede bevegelsene vi ser i regionen har vært uttrykk for en eller annen form for politisk misnøye, eller en eller annen form for alternativt politisk prosjekt. På grunn av endringene i verden har de utviklet også mer globale strategier.

Et godt eksempel på dette er etableringen av al-Qaeda i det islamske Maghreb (AQIM) i 2007, i grenseområdene mellom Mali og Algerie. Dette var ledd i en overlevelsesstrategi. For hvem var disse menneskene da de tok navnet al-Qaeda? Det var en ganske så brokete gruppe menn fra Algerie som hadde søkt tilflukt i NordMali - et område som i lengre tid kun sporadisk hadde vært under kontroll av den maliske staten. De hadde tapt borgerkrigen i Algerie. Det var ingen fremtid der. Det var ingen vei tilbake. De ville ikke være med på amnestiprogrammet som regjeringen i Algerie lovet. Det var ingen som ville forhandle med dem. De hadde lite eller ingen ting å tape og potensielt sett en god del å vinne på å ta dette navnet, og det var mulig for dem å finne tilhold, planlegge og utvikle nye strategier i perifere deler av Sahel som Nord-Mali hvor statsmakt i den grad den fortsatt er tilstede er oppfattet som svak, irrelevant og lite troverdig (Bøås \& Torheim 2013; Bøås 2014).

Spørsmålet er om vi kan gjøre mer i slike områder som dette og hvis så, kan mindre deler av Oljefondet benyttes til denne oppgaven? Ikke som almisser og gaver, men som en kilde til risikovillig kapitalinvestering som kan skape rom både for bedre kollektiv sikkerhet og økonomisk gevinst på lang sikt.

Dette er ikke umulig, men det krever nytenkning. Det store problemet i dag knyttet til bistand så vel som utenlandsinvesteringer i fattige områder er at de landene hvor det er lettest å drive slik virksomhet er de som trenger det minst. De stedene som absolutt trenger dette mest, er der det er vanskeligst å drive med dette. Det å drive med langsiktig bistand og økonomiske investeringer for global sikkerhet $i$ et område som Sahel er en risikosport, men det er også en risikosport som den rikere delen av verden er nødt til å delta aktivt i.

Dette er deler av verden der vi må glemme en del av de betingelsene vi pålegger moderne bistand og utenlandsinvesteringer, med krav om godt styresett, ansvarlighet, menneskerettigheter og andre deler av den liberale bistands- og investeringspakken, herunder null-toleranse for korrupsjon. Denne tilnærmingen vil ikke fungere i slike svake stater. Snarere må man tenke på norsk økonomisk engasjement i slike regioner som en langsiktig investering for å prøve og få til en gradvis re-stabilisering.

En slik satsning vil måtte skje i samspill med et FN som opererer annerledes enn det organisasjonen tradisjonelt sett har gjort. Dette vil blant annet innebære et FN som er mye mer aktivt deltakende i det økonomiske dagligliv i de områdene hvor 
organisasjonen er tungt inne. Det kan ikke lengre være slik at fredsbevarende styrker lever i sin egen økonomiske boble, separert fra lokalbefolkningen (Jennings \& Bøås 2015). Denne satsningen må også foregå i samspill med et bistandsregime som opererer etter den logikken som er dominerende lokalt, og ikke kun baserer seg på ideer som er klekket ut på møter og seminarer i Oslo, Stockholm, Brussel eller New York. Dette er den eneste måten det internasjonale samfunnet igjen kan begynne å bli relevant i disse områdene. Det store problemet i dag er at vi ikke er spesielt relevante for folk som fortsatt bor i disse områdene. Hvis vi i det hele tatt er tilstede, så er vi sjelden tilstede på en slik måte at lokalbefolkningen klarer å nyttiggjøre seg vår tilstedeværelse.

\section{Mali - et norsk fokusland}

Mali er en fattig og sårbar stat i Sahel-regionen og norske myndigheter har utropt Mali til et fokusland for norsk bistand. Som andre sårbare stater i denne delen av Afrika er Mali preget av høy befolkningsvekst - landet har 16 millioner innbyggere, en befolkningsvekst på 3 prosent per år, og 50 prosent av befolkningen er under 50 år. Dermed er landet også preget av stor arbeidsledighet spesielt blant de unge, og tre av fire av landets innbyggere har mindre enn 2 dollar å leve for om dagen. Dette gjør at kampen om tilgang til vann og dyrkbar mark tilspisses. Denne kampen blir ikke mindre spent av at landet har et svært dårlig fungerende rettssystem og at korrupsjon er utbredt. Dertil er konfliktbildet i Mali svært komplekst. Det eksisterer både religiøse og mer sekulært orienterte ikke-statlige væpnede bevegelser som opererer i samme område som mer kriminelt organiserte nettverk. Spørsmålet er, hva vil Norge med Mali som et fokusland? Ønsker vi et tyngre norsk engasjement utover de midlene vi allerede bruker og som hovedsaklig går gjennom multilaterale kanaler eller via ikke-statlige internasjonale organisasjoner? Hvordan kan Norge sammen med det internasjonale samfunn bli mer relevante for den maliske befolkningen og bidra til å bøte på Malis mangslungne utfordringer?

Dette er ingen lett oppgave, og den blir heller ikke lettere av at sikkerhetssituasjonen i Mali ikke ser ut til å bli spesielt mye bedre på tross av at en større FNstyrke står i landet. Angrepet på Radisson-hotellet i hovedstaden Bamako i slutten av november 2015, viser med all tydelighet hvor utfordrende sikkerhetssituasjonen i landet har blitt. Norske myndigheter oppfordrer da også alle som ikke absolutt må reise dit til å holde seg unna, og $\mathrm{i}$ alle fall unngå enhver form for ferdsel utenfor Bamako (Se Regjeringen.no 2015). Spørsmålet er om dette er veien å gå?

Vi må innse at vi ikke fullt ut kan beskytte oss mot denne typen angrep. De kan forekomme i sårbare, svake stater i Afrika, men de kan også inntreffe i Paris, og vi slutter ikke å reise til Frankrike eller å investere der av den grunn. Responsen på den utfordringen som svake og sårbare stater som Mali representerer for global sikkerhet må derfor være å adressere årsaken til at dette skjer. En mulighet er å begynne å se på økonomi også som en sikkerhetsstrategi.

FN og det internasjonale samfunn vil alltid ha begrensende ressurser $i$ et land som Mali. Det vil aldri være nok. Det internasjonale samfunn vil aldri klare å få full territoriell kontroll over Mali. Vi kan heller ikke løse de grunnleggende problemene 
som ligger innebygd i den maliske staten. Det må malierne selv finne ut av. Men hvis vi ikke bare skal fortsette som nå og holde landet på en form for internasjonalt 'kunstig åndedrett' til lavest mulig kostnad, må vi tenke annerledes.

En mulighet er å se på hvor vi får mest ut av de ressursene vi har tilgjengelig til å re-stabilisere Mali istedenfor å spre dem tynt utover. Det er gode grunner til å anta at en samlet ressursallokering i byen Gao og den tilhørende Gao-regionen ville være det beste grepet for å begynne en slik stabiliseringsprosess. Byen er sentralt plassert langs Niger-elven som er landets livsåre mellom Bamako og de øde ørkenområdene i Kidal. Får man kontroll over Gao får man både kontroll over ferdselen på Nigerelven og over hovedveien ned mot Bamako. I tillegg vil bedre statlig og internasjonal tilstedeværelse i denne byen også innebære bedre kontroll med flyten av mennesker og varer mellom Gao og naboland som Algerie, Libya og Niger. Et sterkere internasjonalt sikkerhetsengasjement her kan berede grunnen både for kortsiktig humanitær assistanse og mer langsiktige økonomiske investeringer. Det er nettopp her visse midler fra Oljefondet kan komme inn. Det trengs langsiktige, risikovillige investeringer som har en strukturendrende økonomisk karakter. Spørsmålet er dermed om det er mulig å identifisere sektorer som både har et potensiale for å skape bedre lokal og dermed global sikkerhet, samtidig som de også har et langsiktig potensiale for økonomisk avkastning.

Dette må studeres og analyseres nærmere, men småskala eksperimenter med nye former for landbruk som er tilpasset de klimatiske endringene regionen opplever kan på lang sikt bli en kilde til stor avkastning. En ny type landbruk vil kunne spre seg fra Sahel til andre områder av verden. Dette området kan også vise seg å ha betydelige forekomster av strategiske mineraler og olje og gass. Sistnevnte er muligens av mindre interesse gitt nåværende lave olje- og gasspriser, men kan fortsatt komme til å ha betydelig økonomisk interesse i fremtiden gitt Afrikas økende energibehov. Turisme er en annen sektor i dette området som kan ha et stort inntjeningspotensiale, gitt en mer stabil fremtid. Mulighetene er i hvert fall tilstede. Det vi snakker om her er ikke betydelige investeringer sett $\mathrm{i}$ forhold til Oljefondets volum, men mindre, strategiske investeringer. For eksempel ved at man oppretter et spesialfond for investeringer i slike stater på siden av selve Oljefondet, men som finansieres av dette fondet.

Det er godt mulig at slike tanker bare vil bli avskrevet som naive av de som ønsker å holde på fondets tradisjonelle modell og operative virksomhet. Likevel, de utfordringene jeg har trukket frem i denne artikkelen forsvinner ikke av seg selv. Gjør vi ikke noe med dem vil vi bare komme til å møte enda større sikkerhetsutfordringer fra sårbare stater i fremtiden. Vi må finne en måte å være nærværende på i slike stater som oppfattes som relevant for deres innbyggere og som samtidig forebygger problemer som fort kan ramme oss selv. Videre må vi ta inn over oss at vi befinner oss $\mathrm{i}$ en tilstand av konkurranse i en situasjon som den i Mali. Det internasjonale samfunn konkurrerer med andre aktører, inkludert væpnende ikke-statlige aktører og kriminelle nettverk, om hvem som er mest relevant i folks kamp for tilværelsen. Vi har neppe råd til å tape denne kampen, men vi har råd til, på kort sikt, å ta noen små strategiske tap fra vårt gigantiske oljefond. 


\section{Avsluttende betraktninger}

Om vi liker det eller ikke, så er allerede Oljefondet giennom sine investeringer en global politisk aktør og dermed også uunngåelig en del av Norge og norsk utenrikspolitikk. I gode, stabile tider var det kanskje mindre grunn til å tenke så nøye igjennom dette, men slik er ikke verden akkurat nå. Verden av i dag er ikke bare i rask endring, den er også blitt mye mer multipolær, uforutsigbar og kaotisk enn hva som var tilfelle kun for noen år tilbake. Dette kommer ikke til å vare evig. Før eller senere vil en ny og mer stabil verdensorden manifestere seg både politisk og økonomisk. Likevel, jo fortere vi kommer oss gjennom den nåværende perioden, jo bedre også for Norge og for vår globale formue som er plassert $\mathrm{i}$ ulike investeringsobjekter verden rundt. Det er derfor ikke naivt å begynne å tenke de tankene dette fokusbidraget trekker opp. Snarere vil jeg hevde at det er i tråd med en type politisk realisme som er nødvendig for en stat som Norge; et land så unikt i global historie som en marginal småstat med økonomisk verdensmakt. Måten vi har organisert forvaltningen av vår enorme oljeformue på er det som har gitt oss denne verdensmakten. Nå er det kanskje på tide å tenke nytt om hvordan forvaltningen av nasjonalformuen skal sikre våre bredere interesser i fremtiden, interesser som med nødvendighet må knyttes til kollektiv global sikkerhet.

\section{Referanser}

Bjørgo, Narve (1995) Selvstendighet og Union: Fra Middelalderen til 1905. Oslo: Universitetsforlaget.

Bøås, Morten (2015) «Crime, Coping and Resistance in the Mali-Sahel Periphery», African Security, 8 (4): 299-319.

Bøås, Morten (2014) «Guns, Money and Prayers: AQIM's Blueprint for Securing Control of Northern Mali», CTC Sentinel, 7 (4): 1-7.

Bøås, Morten og Liv-Elin Torheim (2013) «The Trouble in Mali - Corruption, Collusion, Resistance», Third World Quarterly, 34 (7): 1279-1292.

Jennings, Kathleen \& Morten Bøås (red.) (2015) «Service, Sex and Security: Everyday Life in the Peacekeeping Economy», Special Issue of the fournal of Intervention and Statebuilding, 9 (3): 281-407.

Regjeringen. no (2015) Mali - Reiseinformasjon. Tilgjengelig på https://www.regjeringen.no/no/tema/uten rikssaker/reiseinformasjon/velg-reiserad/offisielt-reiserad-for-mali/id2422768/. Lesedato 05.01.16.

Simensen, Jarle (2003) Norge Møter Den Tredje Verden 1952-1975. Bergen: Fagbokforlaget.

Sverdrup, Ulf (2013) «Gorillaen i Utenrikspolitikken». Tilgjengelig på https://www-biz.no/bizreview/artikler/ gorillaen-i-utenrikspolitikken/. Lesedato 16.12.15.

Utenriksdepartementet (2015) Den afrikanske union og Norge inngår strategisk partnerskap. Tilgjengelig på https:/www.regjeringen.no/no/aktuelt/au_samarbeid/id2363711/. 